\title{
Medo da violência e adesão ao autoritarismo no Brasil: proposta metodológica e resultados em 2017
}

\author{
Renato Sérgio de Lima1 (i) \\ Paulo de Martino Jannuzzi ${ }^{2}$ \\ James F. Moura Junior ${ }^{3}$ \\ Damião S. de Almeida Segundo ${ }^{4}$
}

\begin{abstract}
O presente artigo examina o apoio da população brasileira a posições autoritárias e, de forma ampla, dialoga com as preocupações com os recentes rompimentos democráticos e o fortalecimento de posições antidemocráticas após 30 anos da Constituição Federal. Para tanto, foi realizado um levantamento com uma amostra representativa da população adulta a partir dos 16 anos. Foram entrevistadas 2.087 pessoas que responderam a uma versão de 17 itens da escala de autoritarismo de Adorno (Escala F). Os resultados indicam uma forte adesão às posições autoritárias em todos os estratos sociais, mas ainda mais intensas para segmentos sociais historicamente marginalizados. O medo da violência, que tem sido eficazmente explorado pelos porta-vozes da extrema direita política para o reforço do pânico moral, pode ter sido o propulsor das tendências autoritárias.
\end{abstract}

Palavras-chave: autoritarismo; Brasil; medo; democracia

\section{Introdução}

O autoritarismo se refere a um conjunto de crenças, sentimentos e atitudes antidemocráticas e preconceituosas, relacionadas a submissão e agressividade autoritária e à defesa de valores e instituições convencionais ou conservadores (Crochík, 2005). No Brasil, o preconceito é um fenômeno abrangente, cujas origens remontam à sua formação autoritária como povo e nação, sendo concebido como um conjunto de informações

\footnotetext{
${ }^{1}$ Fundação Getúlio Vargas, Departamento de Gestão Pública Eaesp. Fórum Brasileiro de Segurança Pública. Pesquisador do CNPq com Bolsa PQ. São Paulo (SP), Brasil. E-mail: <renato.lima@forumseguranca.org.br>. 2 Escola Nacional de Ciências Estatísticas do Instituto Brasileiro de Geografia e Estatística (Ence/IBGE). Escola Nacional de Administração Pública. Pesquisador PQ/CNPq. Rio de Janeiro (RJ), Brasil.

E-mail: <paulo.jannuzzi@ibge.gov.br>.

3 Universidade da Integração Internacional da Lusofonia Afro-Brasileira (Unilab). Redenção. Universidade Federal do Ceará (UFC). Programa de Pós-Graduação em Psicologia. Fortaleza (CE), Brasil.

E-mail:<jamesferreirajr@gmail.com>.

${ }^{4}$ Universidade Federal do Ceará (UFC). Programa de Pós-Graduação em Psicologia. Fortaleza (CE), Brasil. E-mail: <damiao_soares@hotmail.com>.
} 
negativas constituído de aspectos cognitivos, afetivos e comportamentais impetrados a um determinado grupo social (Paluck e Green, 2009). Essa generalização atinge diversos grupos, como as pessoas com transtorno mental (Salles e Barros, 2013), a população negra (Nogueira, 2007), os gays, lésbicas e transgêneros (Costa et al., 2015) e as pessoas em situação de pobreza (Narayan, 2000).

Portanto, o preconceito é uma crença preconcebida sobre algum grupo ou temática. Ele está baseado em uma forma de reconhecimento depreciativo do outro. Entende-se que essa crença é amparada por um contexto social. É importante salientar que as subjetividades humanas são desenvolvidas a partir do imaginário social. Ou seja, os seres humanos pensam, agem, sentem e refletem a partir de discursos sociais pertencentes a uma determinada realidade social e/ou contexto. Assim, os signos e os símbolos da linguagem constituem a consciência do indivíduo, repercutindo nas suas formas de pensar e de agir sobre a realidade (Codo, 1994). O autoritarismo, então, seria uma tendência presente na sociedade que impacta nos modos de agir dos indivíduos.

O autoritarismo é um traço constante na história do Brasil. Na Colônia, o autoritarismo manifestou-se pela escravização de índios e negros e pela violência com que eram dizimados os indivíduos que se revoltavam contra essa condição (Grosfoguel, 2016). No período pós-abolição, essa cultura escravocrata autoritária legitimava diferentes formas de tratar - e matar - negros e pobres no país (Mbembe, 2017). O Brasil republicano vivenciou diversos momentos autoritários, cada qual com diferentes mecanismos de vigiar a sociedade e punir os então considerados subversivos, comunistas e agitadores (Schwartzman, 2007).

No limite, a violência faz parte da história das relações sociais no Brasil e é aceita como forma legítima de solução de conflitos em várias esferas - da violência doméstica à violência do Estado, passando pela violência e dominação das organizações criminosas de territórios e prisões (Lima, 2018). Tanto é que, para muitos sociólogos e cientistas políticos, o país nunca deteve o monopólio da violência do Estado dentro de parâmetros democráticos (Adorno e Dias, 2014), em muito derivado da convivência com aquilo que Paulo Sérgio Pinheiro (1991) chamou de "autoritarismo socialmente implantado", isto é, com padrões dependentes de sistemas de hierarquia e de poder que apartam a população em dois grandes grupos, que, nos anos 1980, eram os "trabalhadores" versus os "vagabundos" e, nos 2000, os "cidadãos de bem" versus "bandidos". Aos primeiros, a Lei. Aos segundos, a repressão dos organismos de Estado voltados a manter uma ordem social desigual e violenta.

E, para explicar essa separação da sociedade brasileira em dois grandes grupos, Lima (2018) recupera vários autores (Alba Zaluar, Paulo Sérgio Pinheiro, Sérgio Adorno, Wanderley Guilherme dos Santos, Teresa Caldeira, James Holston, entre outros) que se dedicaram a compreender as formas e as clivagens socioeconômicas, demográficas, políticas e territoriais que acionam os mecanismos de rotulação e classificação de cidadãos como integrantes de um e/ou de outro grupo para defender a ideia de que violência, medo 
e crime ocupam papéis-chave na construção de representações sociais sobre como as respostas públicas frente aos desafios da segurança e da manutenção da ordem se estruturam. Ainda mais em um cenário no qual a política criminal e as instituições que compõem o sistema de justiça criminal do país não foram transformadas por completo pela redemocratização brasileira e ainda são operadas por leis e doutrinas autoritárias que aceitam a violência como uma das linguagens legítimas.

Desse modo, a Constituição Federal de 1988 é um marco na luta por direitos civis, sociais e políticos, e estabeleceu limites para discricionariedade autoritária (Sprandel, 2004), mas não transformou a arquitetura das instituições de justiça e de segurança (Lima, 2018). A Constituição foi um marco na construção da democracia. Porém, em que pese a vertebração de direitos sociais concretos, como discutido em Moura Jr., Ximenes e Sarriera (2014), a fragilidade das instituições construídas e a força da vertente autoritária de segmentos da sociedade brasileira mostraram-se por demais resilientes e nos provocam a refletir sobre os elementos que estão a informar as representações sociais que movem a adesão ao autoritarismo no país.

Este artigo tem como objetivo analisar a propensão da população brasileira ao apoio a posições autoritárias, a partir de pesquisa nacional realizada em março de 2017, com uma amostra representativa da população adulta com 16 anos ou mais de idade por unidade da federação. Em termos mais amplos, o artigo dialoga com a preocupação contida em Lima (2018), que, passados 30 anos da promulgação da Constituição Federal e com a emergência de diversos sinais que indicam o refortalecimento de narrativas conservadoras e autoritárias na vida política brasileira, alerta para o perigo da "desconsolidação" da democracia 5 enquanto regime de governo mais adequado para administrar os conflitos sociais modernos. Para tanto, no tópico "O dimensionamento do autoritarismo", apresentase um breve panorama das primeiras pesquisas empíricas sobre o autoritarismo e da mensuração do construto, principalmente a criação da escala $\mathrm{F}$ e a perspectiva atual de sua dimensionalidade. Em seguida, no tópico "A proposta metodológica de dimensionamento do autoritarismo", são discutidos os estudos brasileiros com a escala $\mathrm{F}$ que serviram como base para o método do presente artigo e são relatados alguns dos resultados para os 17 itens da versão da escala F aplicada. No terceiro tópico, "Propensão ao autoritarismo segundo diferentes recortes analíticos", são apresentados e discutidos os resultados acerca da propensão ao autoritarismo no Brasil para distintos recortes, como: faixa etária, cor/raça, classe econômica, macrorregião, porte do município e escolaridade. Por fim, em "À guisa de conclusão: o que pode ser feito para sair dessa situação?", discutimos as implicações dos resultados encontrados em 2017 e as repercussões para o contexto brasileiro atual, com o fortalecimento da ultradireita e o retrocesso na agenda de direitos civis, políticos e sociais.

\footnotetext{
5 Termo utilizado por Foa e Mounk (2016) para os contextos dos EUA e da Europa, que também enfrentam ondas autoritárias, derivadas principalmente das crises com refugiados e do medo do terrorismo religioso.
} 


\section{O dimensionamento do autoritarismo}

Personalidade autoritária é um tema de investigação com longa tradição na psicologia política, com origens remontando à década de 1940 e, não por acaso, segundo Bernal (1982), motivado pelo acirramento do preconceito contra judeus e pelo genocídio por que passaram milhões deles na Alemanha nazista. $O$ autor atribui às contribuições de Erich Fromm e, em especial, de Theodor Adorno e colegas a abertura desse programa de investigação, que se consolidaria nas décadas seguintes em diversos países.

A explicitação do conflito societal e pessoal entre escolhas de maior liberdade ou maior segurança seria, na análise de Bernal (1982), uma contribuição fundamental de Fromm ao tema do autoritarismo. Em seu livro, publicado em 1941 no exterior e em 1983 no Brasil, o psicanalista alemão (e judeu emigrado para os EUA) propôs que o homem, quanto mais ganha em liberdade, mais perde em segurança. Em períodos de crise, em que as pessoas se sentem mais inseguras e impotentes, mais agudo seria esse conflito de valores e mais fértil seria o terreno para o avanço do autoritarismo (Fromm, 1983).

Foi Fromm quem primeiro notou a relação entre o nazismo e o autoritarismo. Em sua obra, o autor destacou uma das principais características vinculadas à personalidade autoritária: a orientação ambivalente entre autoridade e poder (Fromm, 1983). Segundo esse autor, o indivíduo autoritário é, a um só tempo, submisso e dominador: submisso em relação àqueles que percebe como mais fortes - autoridade - e dominador diante daqueles que julga mais fracos (Teixeira e Polo, 1975, p. 48). Frenkel e Sanford discutiram traços mais gerais associados à atitude antissemita que chamou de etnocentrismo e foi medida pela escala E. No entanto, foi a seminal publicação de Theodor Adorno e colegas que se tornou o principal instrumento para mensuração de personalidades autoritárias, chamada de escala F (Fascismo). O livro Personalidade autoritária (Adorno et al., 1950) é reconhecido como primeira e principal referência nas pesquisas posteriores sobre o tema por apresentar uma forma de mensurar o grau de autoritarismo prevalecente na população. Nesse trabalho, Adorno e colaboradores procuraram avaliar o preconceito etnocêntrico e mensurar as disposições a concepções autoritárias de uma personalidade potencialmente fascista. A bateria psicométrica de quesitos que compôs a escala $F$ foi uma proposta metodológica com grande repercussão no meio acadêmico, influenciando até hoje programas de pesquisa na área entre sociólogos, cientistas políticos e psicólogos sociais. De forma sucinta, como registram Bernal (1982) e Barros, Torres e Pereira (2009), a proposta dessa escala refere-se à avaliação da suscetibilidade individual a valores autoritários. Ela se estruturaria em torno de vários subconstructos latentes, entre os quais o convencionalismo (adesão aos valores tradicionais e convenções da sociedade), a submissão à autoridade (aceitação incondicional a uma liderança reconhecida como legítima) e a agressividade autoritária (predisposição à hostilidade de minorias).

Ainda segundo Barros, Torres e Pereira (2009), não poderia ser mais atual a constatação clássica desse estudo seminal: 
Para Adorno e colegas, os indivíduos que são socializados numa sociedade sob um regime político autoritário tendem a se submeter às autoridades e a se posicionar no lado político dominante. Esses indivíduos nutrem uma confiança excessiva nas autoridades e tornam-se mais predispostos ao autoritarismo por acreditarem que compartilham o poder e a fama daqueles que apoiam. Por outro lado, a internalização dessas normas exerceria a função de proteção nos momentos em que figuras de autoridade não estiverem presentes, minimizando a ansiedade. E mais, qualquer crítica feita a essas normas é vista pelo indivíduo como um ataque à própria pessoa (Barros, Torres e Pereira, 2009, p. 48).

Portanto, a escala psicométrica elaborada por Adorno e colaboradores (1950) foi desenhada com o objetivo de medir tendências antidemocráticas implícitas na personalidade dos indivíduos. O conjunto de frases que compõem o formulário empregado na pesquisa pretendia aferir a adesão a assertivas autoritárias sem explicitar, no entanto, o objetivo de investigar essa adesão ao autoritarismo. O questionário se apresentava como um levantamento geral de opinião pública sobre questões cotidianas (Adorno et al., 1950). Os indivíduos não foram questionados diretamente sobre seu posicionamento político e ideológico. Desse modo, pretendia-se identificar, nos Estados Unidos dos anos 1950 (apenas cinco anos após o término da Segunda Guerra Mundial), uma potencial receptividade da população à propaganda antidemocrática e, com isso, perceber tendências de crescimento do autoritarismo em um país democrático.

As primeiras versões do questionário utilizado visaram estimar, ainda de modo exploratório, a adesão a ideias autoritárias correlatas ao nazismo: antissemitismo, etnocentrismo e conservadorismo político-econômico. Essas foram as escalas testadas inicialmente. Com o desenvolvimento da pesquisa, foi possível compor um único formulário de 78 itens com o objetivo de medir a ideologia subjacente aos três grupos. Esse novo instrumento foi chamado de escala $F$, em função de seu objetivo de captar tendências préfascistas implícitas (Adorno et al., 1950). As questões também foram validadas em estudos de caso: grupos focais e entrevistas clínicas com indivíduos com pontuações distintas na escala. À medida que novos estudos eram realizados para aprimorar a confiabilidade da medida, diminuía-se o número de itens da escala. Desse modo, se o primeiro formulário tinha 78 itens, aos poucos ele foi sendo calibrado e passou para 60, 45 e, por fim, 40 assertivas. As afirmações do formulário se distribuíam em nove dimensões: submissão à autoridade; agressividade autoritária; convencionalismo; anti-introspecção; superstição e estereotipia; poder e "dureza"; destrutividade e cinismo; projetividade; preocupação com o sexo.

A dimensão "convencionalismo" media à época a adesão rígida a valores convencionais da classe média norte-americana dos anos 1940, um apego às normas morais e uma inclinação a punir quem não as seguia. A afirmação "Um indivíduo de más 
maneiras, maus costumes e má educação dificilmente pode fazer amizade com pessoas decentes" denota esse apego a imagens do que seria uma pessoa decente e de quem seriam os indivíduos com os quais ela se relacionava. O item que divide os homens em duas categorias, "os fracos e os fortes", mede também a adesão a categorias fechadas e convencionais. Como afirmam Adorno et al. (1950), o indivíduo que segue convenções também pode mudar facilmente de um conjunto de padrões a outro, de uma ideologia a outra. No entanto, mesmo com a mudança de padrão, a estrutura de classificação e hierarquização ainda permanece. A personalidade apegada a valores convencionais possui grande potencial de seguir e fazer o que lhe é dito por agência externa, não importa o teor do pedido. Outro fator importante do "convencionalismo" é o pensamento em categorias rígidas e a crença em causas externas fantásticas ou místicas que determinam o destino dos indivíduos, que os autores chamam de superstição, como capta a afirmação "A ciência tem o seu lugar, mas há muitas coisas importantes que a mente humana jamais poderá compreender". No limite, a adesão a esses valores indica a tendência de retirar do indivíduo a responsabilidade por seus próprios atos.

A dimensão "submissão à autoridade" representa a tendência ou desejo de adotar uma atitude submissa e acrítica perante as autoridades morais idealizadas em determinado grupo social. Está associada ao desejo de um líder forte e moralmente respeitado. A concordância com os itens dessa dimensão não denota apenas um respeito equilibrado e razoável a uma autoridade válida, derivada de normas e acordos socialmente construídos, mas uma necessidade exagerada de submissão a uma pessoa idealmente detentora de carisma e "virtudes" morais específicas. É o que está indicado quando se diz que "A obediência e o respeito à autoridade são as principais virtudes que devemos ensinar às nossas crianças". Nesse sentido, não se indica uma visão crítica dos rumos da sociedade, apenas a obediência servil e, no limite, opressora. A "submissão à autoridade" contribui para o potencial antidemocrático pois indica a receptividade dos indivíduos a serem orientados por forças externas mais fortes sem questionamentos ou criticidade. Significa dizer que apenas esse líder forte pode indicar os caminhos que a sociedade deverá percorrer, ainda que impliquem a opressão de grupos sociais minoritários dentro dessa mesma sociedade e a indisposição e desvalorização em relação ao dissenso, próprio de uma arena política democrática.

Já a dimensão "agressividade autoritária" pretende medir a tendência a procurar, condenar, rejeitar e punir (violentamente) as pessoas que violam os valores convencionais e tradicionais, mesmo quando resultam em opressão. Está fortemente relacionada à dimensão "submissão à autoridade". É o que está presente na declaração "A maioria de nossos problemas sociais estaria resolvida se pudéssemos nos livrar das pessoas imorais, dos marginais e dos pervertidos". Categorias como "imoralidade", "perversão" e "marginalidade" demarcam distinções entre valores sociais de determinado grupo social e práticas de um grupo social. Nesse sentido, não há abertura para crítica desses valores (que apenas podem ser obedecidos) e deve haver punição para quem não compactua com 
eles. Em relação à realidade brasileira, essa questão lembra a recente onda moralista, que clama por censura e denuncia exposições artísticas e culturais que recorrem à nudez e as tratam, independentemente de maiores apurações, como imorais e incitadoras de pedofilia. Adicionalmente, essa dimensão também se caracteriza pela oposição ao que é difícil de compreender, à introspecção, à imaginação e à intelectualidade, como atesta a afirmação "Se falássemos menos e trabalhássemos mais, todos estaríamos melhor".

Vale registrar que, ao longo dos últimos 50 anos, diversos pesquisadores debruçaram-se sobre a proposta original dos autores, apontando suas limitações, virtudes e correlações - em maior ou menor intensidade - com outros constructos como preconceito, conservadorismo e adesão às teses políticas da direita. Na atualidade, pelo que atesta Etchezahar (2012), a conceituação e operacionalização do constructo da personalidade autoritária com maior consenso é a proposta pelo psicólogo Robert Altemeyer, conhecida como comportamento autoritário das direitas (RWA, acrônimo de right wing authoritarism), proposta nos anos 1980. De fato, pela revisão de trabalhos mais atuais na área, a RWA é reconhecida como uma proposta metodológica mais aprimorada e robusta, ainda que os constructos latentes originais e a forma de avaliá-los guardem muito da proposta original de Adorno e colegas (1950). A RWA compartilha os três constructos latentes da proposta original de dimensionamento do autoritarismo convencionalismo, submissão à autoridade e agressividade autoritária - , mas se revela mais consistente e instrumental quando procura investigar ou predizer atitudes preconceituosas (relacionadas a sexismo, homofobia, racismo, etnocentrismo), obediência à autoridade, fundamentalismo religioso, conservadorismo ou aceitação de transgressão de direitos constitucionais (Etchezahar, 2012; Cárdenas e Parra, 2010).

\section{A proposta metodológica de dimensionamento do autoritarismo}

A proposta de dimensionamento do autoritarismo na população brasileira aqui apresentada foi desenvolvida a partir de quesitos encartados em uma pesquisa amostral de cobertura nacional realizada pelo Fórum Brasileiro de Segurança Pública em parceria com o Datafolha em março de 2017. Por questões de custo, foram selecionados 15 itens com maiores cargas fatoriais da escala medida por Crochík (2005), pesquisador que mais se notabilizou no Brasil no uso desses tipos de escalas psicométricas ${ }^{6}$.

Como a pesquisa desenvolvida tinha que ser de rápida aplicação, foi construído um índice de apoio a posições autoritárias com a redução do número de enunciados da escala $\mathrm{F}$, distribuindo as assertivas selecionadas pelas suas cargas fatoriais de forma equilibrada

\footnotetext{
6 Em sua pesquisa sobre autoritarismo, aplicada em 139 estudantes de administração de empresas e de psicologia no início dos anos 2000 no estado de São Paulo, o autor partiu do formulário de 40 itens da escala $\mathrm{F}$ de Adorno e colaboradores, mas o reduziu e o validou em uma versão com 28 itens (teste de validade alpha de Cronbach igual a 0,84). Além da escala F, Crochík empregou outras três escalas desenvolvidas por ele: escala de ideologia da racionalidade tecnológica, de características narcisistas de personalidade e de manifestação de preconceitos.
} 
de acordo com as três subdimensões estruturantes que Adorno e, posteriormente, Crochík conceituaram como fenômenos associados a posturas autoritárias - submissão à autoridade, agressividade autoritária e convencionalismo (Quadro 1). Adicionalmente, incluíram-se dois novos enunciados, um no intuito de mensurar a eventual influência da religiosidade na construção das representações sociais acerca da identidade dos policiais brasileiros ("O policial é um guerreiro de Deus para impor a ordem e proteger as pessoas de bem") e outro, para mensurar eventual preconceito com pobres após vários anos de investimento em programas de transferência de renda e combate à pobreza extrema ("Pobreza é consequência da falta de vontade de querer trabalhar").

Com essas 17 assertivas em mãos ${ }^{7}$, o Datafolha aplicou 2.087 entrevistas, em uma amostra estatisticamente representativa da população brasileira com 16 anos ou mais e em 130 municípios de pequeno, médio e grande porte, entre os dias 7 e 11 de março de 2017. A amostra permite a leitura dos resultados por macrorregião do país, sendo que a margem de erro da pesquisa é de 2 pontos para mais ou para menos, considerando um intervalo de confiança de $95 \%$. Na pesquisa se fez uso de técnicas de abordagem pessoal dos entrevistados em pontos de fluxo populacionais a partir de questionários estruturados em seis níveis de concordância em relação às afirmações: concorda totalmente, concorda, concorda parcialmente; discorda parcialmente, discorda e discorda totalmente.

Os resultados descritivos da pesquisa apontam forte concordância com valores típicos do autoritarismo, em especial daqueles relacionados à "submissão à autoridade" (Tabela 1). De fato, 93\% dos entrevistados concordam (em parte, mediana ou totalmente) com a assertiva 3, "A obediência e o respeito à autoridade são as principais virtudes que devemos ensinar às nossas crianças". Na mesma direção, 85\% concordaram com a assertiva 1, "O que este país necessita, principalmente, antes de leis ou planos políticos, é de alguns líderes valentes, incansáveis e dedicados em quem o povo possa depositar a sua fé". Por fim, vale registrar que mais de um terço dos entrevistados revelam menções totalmente concordantes com essas duas assertivas (43\% e 34\%, respectivamente).

\footnotetext{
7 O questionário completo pode ser visualizado no Anexo. A base de dados utilizada está disponibilizada no site do Cesop (cesop.unicamp.br), na seção Revista Opinião Pública, ao final da página correspondente a este artigo em Arquivos Anexados.
} 


\section{Quadro 1 \\ Assertivas utilizadas para dimensionar o grau de propensão ao apoio a posições autoritárias na população brasileira (com 16 anos ou mais), por subdimensão latente}

\begin{tabular}{|c|c|c|}
\hline Submissão à autoridade & Agressividade autoritária & Convencionalismo \\
\hline $\begin{array}{l}\text { O que este país necessita, } \\
\text { principalmente, antes de leis ou } \\
\text { planos políticos, é de alguns líderes } \\
\text { valentes, incansáveis e dedicados } \\
\text { em quem o povo possa depositar a } \\
\text { sua fé. }\end{array}$ & $\begin{array}{l}\text { A maioria de nossos } \\
\text { problemas sociais estaria } \\
\text { resolvida se pudéssemos } \\
\text { nos livrar das pessoas } \\
\text { imorais, dos marginais e } \\
\text { dos pervertidos. }\end{array}$ & $\begin{array}{l}\text { A ciência tem o seu lugar, } \\
\text { mas há muitas coisas } \\
\text { importantes que a mente } \\
\text { humana jamais poderá } \\
\text { compreender. }\end{array}$ \\
\hline $\begin{array}{l}\text { A obediência e o respeito à } \\
\text { autoridade são as principais } \\
\text { virtudes que devemos ensinar às } \\
\text { nossas crianças. }\end{array}$ & $\begin{array}{c}\text { Se falássemos menos e } \\
\text { trabalhássemos mais, todos } \\
\text { estaríamos melhor. }\end{array}$ & $\begin{array}{l}\text { Os homens podem ser } \\
\text { divididos em duas classes } \\
\text { definidas: os fracos e os } \\
\text { fortes. }\end{array}$ \\
\hline $\begin{array}{l}\text { Não há nada pior do que uma } \\
\text { pessoa que não sente profundo } \\
\text { amor, gratidão e respeito por seus } \\
\text { pais. }\end{array}$ & $\begin{array}{l}\text { Deve-se castigar sempre } \\
\text { todo insulto à nossa honra. }\end{array}$ & $\begin{array}{l}\text { Um indivíduo de más } \\
\text { maneiras, maus costumes } \\
\text { e má educação dificilmente } \\
\text { pode fazer amizade com } \\
\text { pessoas decentes. }\end{array}$ \\
\hline $\begin{array}{l}\text { Nenhuma pessoa decente, normal e } \\
\text { em seu são juízo pensaria em } \\
\text { ofender um amigo ou parente } \\
\text { próximo. }\end{array}$ & $\begin{array}{l}\text { Os crimes sexuais tais } \\
\text { como o estupro ou ataques } \\
\text { a crianças merecem mais } \\
\text { que prisão; quem comete } \\
\text { esses crimes deveria } \\
\text { receber punição física } \\
\text { publicamente ou receber } \\
\text { um castigo pior. }\end{array}$ & $\begin{array}{c}\text { Todos devemos ter fé } \\
\text { absoluta em um poder } \\
\text { sobrenatural, cujas } \\
\text { decisões devemos acatar. }\end{array}$ \\
\hline \multirow[t]{3}{*}{$\begin{array}{l}\text { O policial é um guerreiro de Deus } \\
\text { para impor a ordem e proteger as } \\
\text { pessoas de bem. }\end{array}$} & $\begin{array}{l}\text { Os homossexuais são quase } \\
\text { criminosos e deveriam } \\
\text { receber um castigo severo. }\end{array}$ & $\begin{array}{c}\text { Pobreza é consequência da } \\
\text { falta de vontade de querer } \\
\text { trabalhar. }\end{array}$ \\
\hline & $\begin{array}{l}\text { Às vezes, os jovens têm } \\
\text { ideias rebeldes que, com os } \\
\text { anos, deverão superar para } \\
\text { acalmar os seus } \\
\text { pensamentos. }\end{array}$ & \\
\hline & $\begin{array}{c}\text { Hoje em dia, as pessoas se } \\
\text { intrometem cada vez mais } \\
\text { em assuntos que deveriam } \\
\text { ser somente pessoais e } \\
\text { privados. }\end{array}$ & \\
\hline
\end{tabular}

Fonte: Elaborado pelos autores com base em dados do Datafolha/Fórum Brasileiro de Segurança Pública (2017). 
Também é expressiva a concordância com as frases associadas às subdimensões do convencionalismo. Cerca de $78 \%$ dos entrevistados concordam (em alguma medida) com a assertiva 11, "Todos devemos ter fé absoluta em um poder sobrenatural, cujas decisões devemos acatar", e uma parcela um pouco menor (70\%) avaliza que "Um indivíduo de más maneiras, maus costumes e má educação dificilmente pode fazer amizade com pessoas decentes" (assertiva 9).

Tabela 1

Posicionamento dos respondentes quanto ao grau de concordância e discordância com relação às assertivas investigadas - Brasil, março de 2017 (resposta estimulada e única, em \%)

\begin{tabular}{|c|c|c|c|c|c|c|c|c|}
\hline Assertiva & $\begin{array}{l}\text { Concorda } \\
\text { totalmente }\end{array}$ & Concorda & $\begin{array}{l}\text { Concorda } \\
\text { em parte }\end{array}$ & $\begin{array}{l}\text { Discorda } \\
\text { em parte }\end{array}$ & Discorda & $\begin{array}{l}\text { Discorda } \\
\text { totalmente }\end{array}$ & $\begin{array}{l}\text { Não } \\
\text { sabe }\end{array}$ & Total \\
\hline $\begin{array}{l}\text { 1. O que este país necessita, } \\
\text { principalmente, antes de leis ou planos } \\
\text { políticos, é de alguns líderes valentes, } \\
\text { incansáveis e dedicados em quem o } \\
\text { povo possa depositar a sua fé. }\end{array}$ & 34 & 35 & 16 & 4 & 5 & 4 & 2 & 100 \\
\hline $\begin{array}{l}\text { 2. A maioria de nossos problemas } \\
\text { sociais estaria resolvida se pudéssemos } \\
\text { nos livrar das pessoas imorais, dos } \\
\text { marginais e dos pervertidos. }\end{array}$ & 34 & 35 & 16 & 4 & 5 & 4 & 2 & 100 \\
\hline $\begin{array}{l}\text { 3. A obediência e o respeito à } \\
\text { autoridade são as principais virtudes } \\
\text { que devemos ensinar às nossas } \\
\text { crianças. }\end{array}$ & 43 & 38 & 12 & 3 & 2 & 2 & 1 & 100 \\
\hline $\begin{array}{l}\text { 4. Os homens podem ser divididos em } \\
\text { duas classes definidas: os fracos e os } \\
\text { fortes. }\end{array}$ & 17 & 27 & 15 & 7 & 15 & 17 & 2 & 100 \\
\hline $\begin{array}{l}\text { 5. Deve-se castigar sempre todo insulto } \\
\text { à nossa honra. }\end{array}$ & 16 & 29 & 19 & 9 & 15 & 11 & 2 & 100 \\
\hline $\begin{array}{l}\text { 6. A ciência tem o seu lugar, mas há } \\
\text { muitas coisas importantes que a mente } \\
\text { humana jamais poderá compreender. }\end{array}$ & 33 & 41 & 13 & 4 & 4 & 2 & 3 & 100 \\
\hline $\begin{array}{l}\text { 7. Os crimes sexuais tais como o } \\
\text { estupro ou ataques a crianças merecem } \\
\text { mais que prisão; quem comete esses } \\
\text { crimes deveria receber punição física } \\
\text { publicamente ou receber um castigo } \\
\text { pior. }\end{array}$ & 44 & 25 & 12 & 5 & 7 & 5 & 2 & 100 \\
\hline
\end{tabular}




\begin{tabular}{|c|c|c|c|c|c|c|c|c|}
\hline Assertiva & $\begin{array}{l}\text { Concorda } \\
\text { totalmente }\end{array}$ & Concorda & $\begin{array}{l}\text { Concorda } \\
\text { em parte }\end{array}$ & $\begin{array}{l}\text { Discorda } \\
\text { em parte }\end{array}$ & Discorda & $\begin{array}{l}\text { Discorda } \\
\text { totalmente }\end{array}$ & $\begin{array}{l}\text { Não } \\
\text { sabe }\end{array}$ & Total \\
\hline $\begin{array}{l}\text { 8. Hoje em dia, as pessoas se } \\
\text { intrometem cada vez mais em assuntos } \\
\text { que deveriam ser somente pessoais e } \\
\text { privados. }\end{array}$ & 40 & 39 & 10 & 3 & 4 & 3 & 1 & 100 \\
\hline $\begin{array}{l}\text { 9. Um indivíduo de más maneiras, maus } \\
\text { costumes e má educação dificilmente } \\
\text { pode fazer amizade com pessoas } \\
\text { decentes. }\end{array}$ & 23 & 30 & 17 & 8 & 12 & 8 & 1 & 100 \\
\hline $\begin{array}{l}\text { 10. Se falássemos menos e } \\
\text { trabalhássemos mais, todos estaríamos } \\
\text { melhor. }\end{array}$ & 42 & 34 & 12 & 3 & 4 & 3 & 1 & 100 \\
\hline $\begin{array}{l}\text { 11. Todos devemos ter fé absoluta em } \\
\text { um poder sobrenatural, cujas decisões } \\
\text { devemos acatar. }\end{array}$ & 30 & 34 & 14 & 5 & 8 & 6 & 2 & 100 \\
\hline $\begin{array}{l}\text { 12. Não há nada pior do que uma } \\
\text { pessoa que não sente profundo amor, } \\
\text { gratidão e respeito por seus pais. }\end{array}$ & 51 & 32 & 7 & 3 & 4 & 2 & 1 & 100 \\
\hline $\begin{array}{l}\text { 13. Os homossexuais são quase } \\
\text { criminosos e deveriam receber um } \\
\text { castigo severo. }\end{array}$ & 6 & 7 & 6 & 4 & 23 & 53 & 2 & 100 \\
\hline $\begin{array}{l}\text { 14. Nenhuma pessoa decente, normal e } \\
\text { em seu são juízo pensaria em ofender } \\
\text { um amigo ou parente próximo. }\end{array}$ & 28 & 39 & 14 & 5 & 7 & 5 & 1 & 100 \\
\hline $\begin{array}{l}\text { 15. O policial é um guerreiro de Deus } \\
\text { para impor a ordem e proteger as } \\
\text { pessoas de bem. }\end{array}$ & 22 & 31 & 24 & 7 & 8 & 7 & 1 & 100 \\
\hline $\begin{array}{l}\text { 16. Às vezes, os jovens têm ideias } \\
\text { rebeldes que, com os anos, deverão } \\
\text { superar para acalmar os seus } \\
\text { pensamentos. }\end{array}$ & 25 & 42 & 18 & 4 & 6 & 3 & 2 & 100 \\
\hline $\begin{array}{l}\text { 17. Pobreza é consequência da falta de } \\
\text { vontade de querer trabalhar. }\end{array}$ & 12 & 19 & 16 & 8 & 18 & 26 & 1 & 100 \\
\hline
\end{tabular}

Fonte: Elaborada pelos autores com base em dados do Datafolha/Fórum Brasileiro de Segurança Pública (2017).

A intolerância, e seu correlato, a propensão à agressividade autoritária, é outro resultado da pesquisa. De cada 100 entrevistados, 85 concordam que "A maioria de nossos problemas sociais estaria resolvida se pudéssemos nos livrar das pessoas imorais, dos marginais e dos pervertidos" (item 2) e 64 parecem avalizar punições extremadas mesmo em casos menos graves, como sugere a concordância com a assertiva 5, "Deve-se castigar sempre todo insulto à nossa honra". 
De modo a avançar em perspectiva analítica, buscou-se construir um índice que sintetizasse o conjunto dos itens investigados: o índice de propensão ao apoio a posições autoritárias. As respostas aos itens vinculados à escala $\mathrm{F}$ foram convertidas em um ranking de 1 a 10 pontos: quanto mais próximo de 1 , menor o apoio a posições autoritárias e, quanto mais próximo de 10 , maior a adesão e o apoio a elas.

Na construção do índice, foram descartadas as respostas "Não sabe", e as análises preliminares necessárias à validação da escala permitiram identificar ser adequada a realização de análise fatorial exploratória (AFE), tendo obtido KMO (Kaiser Meyer Olkin) igual a 0,914. O teste de esfericidade de Bartlett apontou $p<0,001$ [X2 (136) = $6483,678]$, indicando valor significativo e rejeição da hipótese nula de matriz de correlação de identidade. Para a extração de fatores, foi feita a análise dos componentes principais, foram examinados os eigenvalues (autovalores) e o gráfico scree plot (gráfico de declive), e foi feita a análise paralela, a fim de determinar a quantidade de fatores a serem extraídos. Após a definição da quantidade de fatores, foi feita a análise de eixos principais, que indicou a solução unifatorial como a mais adequada. Com essa estrutura, foi realizada a análise de confiabilidade da escala, com alpha de Cronbach de 0,824, muito próximo daquele observado por Crochík (2005). Em outras palavras, em termos estatísticos, a escala construída para a mensuração do grau de adesão a posições autoritárias, compreendidas na perspectiva teórica e conceitual consagrada por Adorno e colaboradores (1950), mostrou-se robusta e validada, mesmo com a utilização de uma quantidade menor de enunciados se comparada com os estudos anteriores.

O escore médio de apoio a posições autoritárias no país foi de 8,10 , indicativo de forte propensão de adesão às questões da escala de autoritarismo. As assertivas que mais se destacam no Brasil são aquelas relacionadas à dimensão originalmente nomeada de submissão à autoridade. Encontrar um "salvador", que "coloque ordem na casa", parece ser uma necessidade nacional premente, à luz da pesquisa. As questões relativas a posições convencionais e às atitudes de agressividade autoritária receberam uma adesão um pouco menor. Para conduzir as análises de comparação entre grupos, consideramos a escala em um índice único, com uma solução unifatorial, conforme indicado pela AFE.

Foram realizadas análises de variância (Anovas) comparando o índice de apoio a posições autoritárias a partir de idade, cor, classe, região, porte do munícipio e escolaridade, utilizando o teste post-hoc de Turkey para identificar diferenças entre as médias. Também foi criado o índice de medo da violência a partir das respostas às 16 perguntas vinculadas ao modelo de questão "Você diria que tem medo de..." referentes ao medo de sofrer violência, respondidas com "Sim" ou "Não", por exemplo: "Morrer assassinado?", "Ser vítima de agressão sexual?"8. Em seguida, foram recodificadas as respostas anteriores no banco ( 1 = Sim e 2 = Não) para valores que permitissem a variação entre 0 e 1 ( 0 = Não, 1 = Sim). Para evitar perda amostral, os sujeitos que informaram

\footnotetext{
8 Ver a descrição completa dos 16 itens no questionário anexo.
} 
não ter carro ou moto foram computados como 0 nos itens: "Você diria ter medo de... ter seu carro ou moto tomados de assalto ou furtados?". Por fim, foi calculado o "índice de medo da violência" a partir do somatório dos 16 itens divididos por 16, de forma que o índice varia entre 0 e 1: 0 significando não ter medo de sofrer algum tipo de violência até o máximo de 1, que é o medo de sofrer todos os tipos de violência. Assim, quanto maior o valor do índice, maior o número de violências que se tem medo de sofrer. A amostra foi dividida em dois grupos: a partir de $50 \%$ do percentil mais alto representando mais medo e a partir de $50 \%$ do percentil mais baixo representando menos medo. Esses dois grupos de medo foram comparados a partir de teste t para amostras independentes.

\section{Propensão ao autoritarismo segundo diferentes recortes analíticos}

A análise do índice de propensão ao apoio a posições autoritárias parece seguir, de modo geral, o comportamento esperado segundo os diversos recortes socioeconômicos, demográficos e regionais. Mas, de forma um tanto surpreendente, os níveis de adesão ao autoritarismo são altos nos diversos segmentos populacionais analisados, com algum diferencial - ainda que restrito - segundo classe socioeconômica e nível educacional.

O primeiro aspecto analisado foi o sexo: não houve diferenças estatisticamente significativas ( $F=0,448, p>0,05)$ entre os homens $(M=8,07, D P=1,66)$ e as mulheres $(M=8,12, D P=1,60)$. Em seguida, foi feita uma comparação segundo diferentes faixas etárias.

Com relação aos diferenciais do índice segundo a idade, surpreende pouco o fato de a faixa etária da população com maior adesão ao autoritarismo ser aquela mais velha (Gráfico 1). Foi identificado que os maiores níveis de adesão estão entre as pessoas com mais de 60 anos, enquanto os indivíduos de 25 a 34 anos apresentam menores níveis de adesão $(F=4,426, p<001)$. Todavia, notou-se que a faixa entre 16 e 24 anos de idade demonstra propensão de adesão a posições autoritárias em proporção levemente superior à população acima de 40 anos. A maior adesão a essas posições se dá na faixa etária de 60 anos de idade ou mais, e a menor ocorre na população de 25 a 34 anos de idade. Todas, porém, em níveis muito próximos. Ressalte-se, no entanto, que as únicas diferenças significativas entre as médias são as dos grupos de 25 a 44 anos $(M=7,90, D P=1,92)$, de 45 a 59 anos $(M=8,26, D P=1,57, p=0,007)$ e de 60 anos ou mais $(M=8,31, D P=$ $1,50, p=0,005)$. Nesse processo, considerando os novos grupos e movimentos políticos que ganharam destaque após as manifestações de 2013 e o impeachment da presidente Dilma Rousseff (O MBL - Movimento Brasil Livre - é o caso mais visível), a juventude parece surgir como um fator central para a explicação da atual forte propensão ao autoritarismo captada pelo índice, na medida em que a média apurada para a faixa etária entre 16 e 24 anos de idade é idêntica à média geral da amostra. Também, pode-se sugerir a centralidade das redes sociais e das figuras de autoridade virtual na dinâmica cotidiana 
das populações mais jovens, como também o acesso a smartphones e internet, que são importantes meios de sociabilidade, identitários e de legitimação de opiniões.

Gráfico 1

Índice de propensão a posições autoritárias por faixa etária

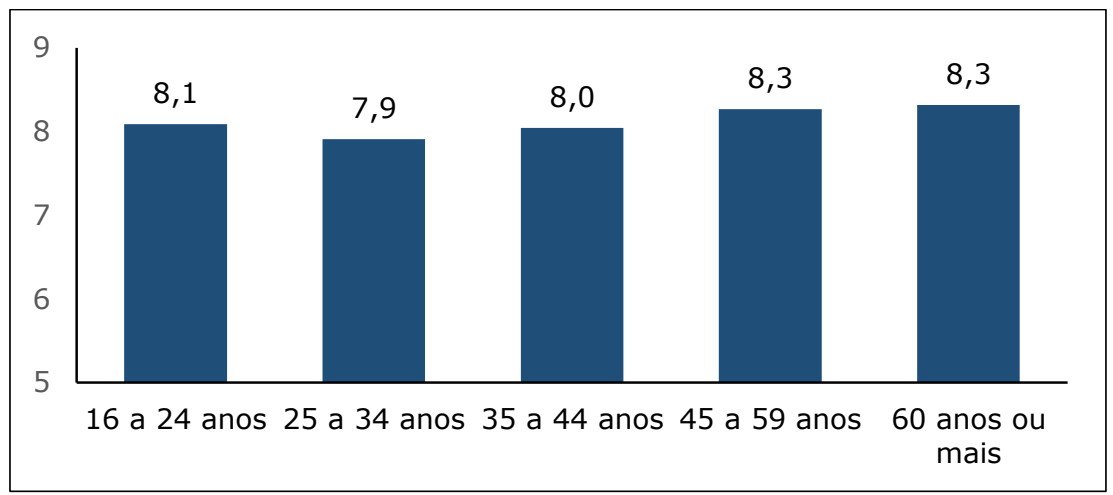

Fonte: Elaborado pelos autores com base em dados do Datafolha/Fórum Brasileiro de Segurança Pública (2017).

Em relação a diferenciais por raça/cor, observa-se que a maior adesão a posições autoritárias se dá entre os autodeclarados pardos, seguidos dos autodeclarados pretos e, depois, dos autodeclarados brancos $(F=6,622, p<0,001)$. Se considerado o intervalo de variação das médias para cada categoria da variável raça/cor, contudo, nota-se que todas variam em um intervalo pequeno, que oscila cerca 0,4 ponto (Gráfico 2). Os autodeclarados pardos foram os que apresentaram maiores médias $(M=8,27, D P=1,41)$. Nesse caso, é necessário avançar na compreensão das razões que fazem com que os pardos tenham se destacado em relação à maior adesão a posições autoritárias. Mas, seja como for, a maior adesão às tendências autoritárias entre os pardos deveria ser considerada como um elemento para reflexão pelo movimento negro no país, que já acumula discussões e conquistas importantes sobre o reconhecimento desse segmento demográfico como componente da população negra brasileira e tem mais condições de compreender e explicar tal fenômeno. 


\section{Gráfico 2}

Índice de propensão a posições autoritárias por cor/raça

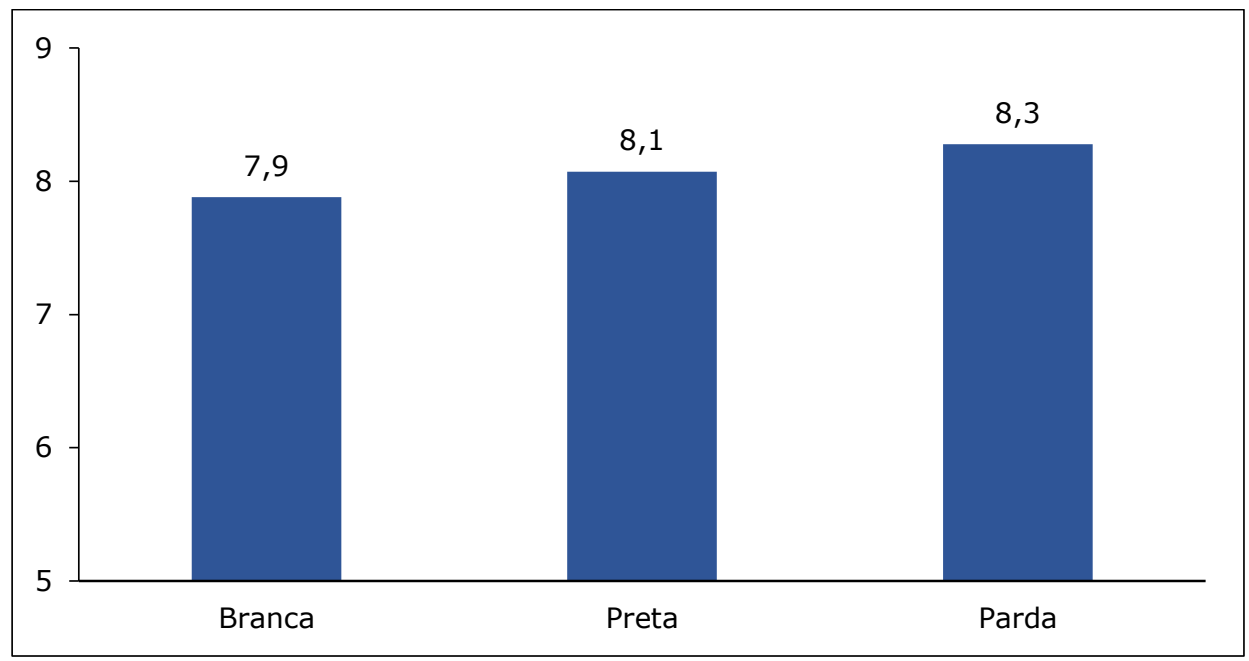

Fonte: Elaborado pelos autores com base em dados do Datafolha/Fórum Brasileiro de Segurança Pública (2017).

Em todas as classes socioeconômicas, a adesão a posturas autoritárias é elevada, de 7,1 a 8,5 entre as classes A e D/E (Gráfico 3). Nesse caso, percebeu-se uma diferença estatisticamente significativa entre as distintas classes sociais $(F=19,305, p<0,001)$ : quanto menor o nível socioeconômico, maior a adesão a valores não democráticos. Por exemplo, a classe $A(M=7,04, D P=1,99)$ apresentou médias mais baixas que a $B 1(M=$ $7,52, \mathrm{DP}=2,00$ ) e a mesma lógica ocorreu com as demais classes. Os resultados parecem indicar que, conforme a população adulta do país avança em termos de bem-estar material, menos suscetível fica em relação às tentações autoritárias. Pode-se destacar que a classe D/E apresentou as pontuações mais elevadas e o maior número de diferenças significativas em relação às outras classes, não se diferenciando apenas da classe C2.

Alguns pontos podem ser destacados e problematizados a título de primeira hipótese a ser explorada por outros estudos. Considerando que a subdimensão latente que apresentou a maior média no Índice foi a da submissão autoritária, que está associada à expectativa de líderes fortes e salvadores da pátria, é possível supor que a maior adesão a posições autoritárias observada nessa categoria da amostra é fruto da correlação dos seguintes fenômenos: 1) as classes D/E são, proporcionalmente, as classes socioeconômicas mais dependentes de programas e políticas sociais, que historicamente apresentam um déficit de cobertura e qualidade no Brasil; 2) os riscos de perdas de benefícios sociais, emprego e renda estão colocados hoje no debate público a partir do agravamento do cenário de crise fiscal e econômica, mas, também, como efeito/subproduto da crise ética e da corrupção do Estado; 3) os integrantes das classes 
D/E são, por fim, aqueles mais suscetíveis de serem vítimas e sofrerem o impacto da violência e da insegurança pública.

A maior adesão ao autoritarismo revelada entre as classes D/E pode ser vista como a tradução da soma de todos os fenômenos acima citados e seria responsável por retroalimentar uma enorme desconfiança e incerteza dessas classes em relação ao Estado e às políticas públicas. Tal processo projeta medos e temores em relação ao futuro e à violência e agrava as profundas carências na incorporação dessas classes como sujeitos de direitos e como atores econômicos na sociedade brasileira. Os pobres hoje estariam decepcionados com os déficits/retrocessos nas políticas sociais e, na inexistência de sólidos anteparos civis e de perspectivas democráticas, estariam mais dispostos do que outros segmentos a embarcar em discursos radicais salvacionistas.

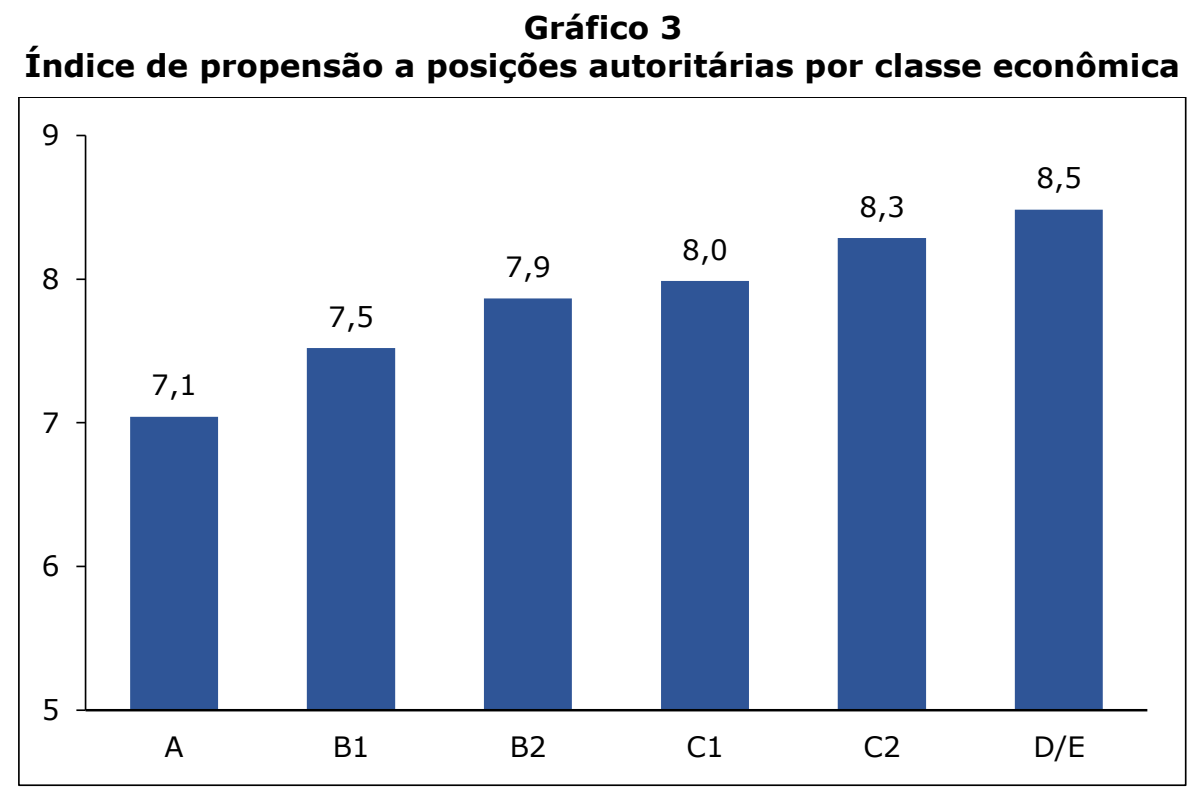

Fonte: Elaborado pelos autores com base nos dados do Datafolha/Fórum Brasileiro de Segurança Pública (2017).

$\mathrm{Na}$ análise desagregada da adesão a posições autoritárias por macrorregiões do país ( $F=7,166, p<0,001$ ), houve somente diferenças significativas de médias entre Sudeste, com a menor média de pontuação de adesão a valores não democráticos ( $M=$ $7,90, D P=1,75, \mathrm{p}<0,001)$, e o Nordeste, com a maior $(M=8,36, D P=1,45)$. Destacase o fato de o Nordeste apresentar índice bem superior $(8,4)$ às demais macrorregiões do país (Gráfico 4). Em termos mais estruturais, a variável que melhor ajudaria a explicar esse comportamento do índice seria, além do peso da classe $D / E$, a violência. É nessa região que as cenas explícitas de barbárie, como as decapitações ou esquartejamentos de presos, ganharam protagonismo, não obstante existirem em várias outras unidades da 
Federação. A rápida mudança no padrão da criminalidade violenta no Nordeste e a insistência das autoridades em vinculá-la exclusivamente à dinâmica do tráfico de drogas parece tensionar ainda mais uma população que, historicamente, construiu sua identidade e suas representações sociais em laços de solidariedade que, na atualidade, são postos à prova pelas diversas transformações da sociedade brasileira e pelas contínuas crises e déficits civis acumulados.

Gráfico 4

Índice de propensão a posições autoritárias por macrorregião do país

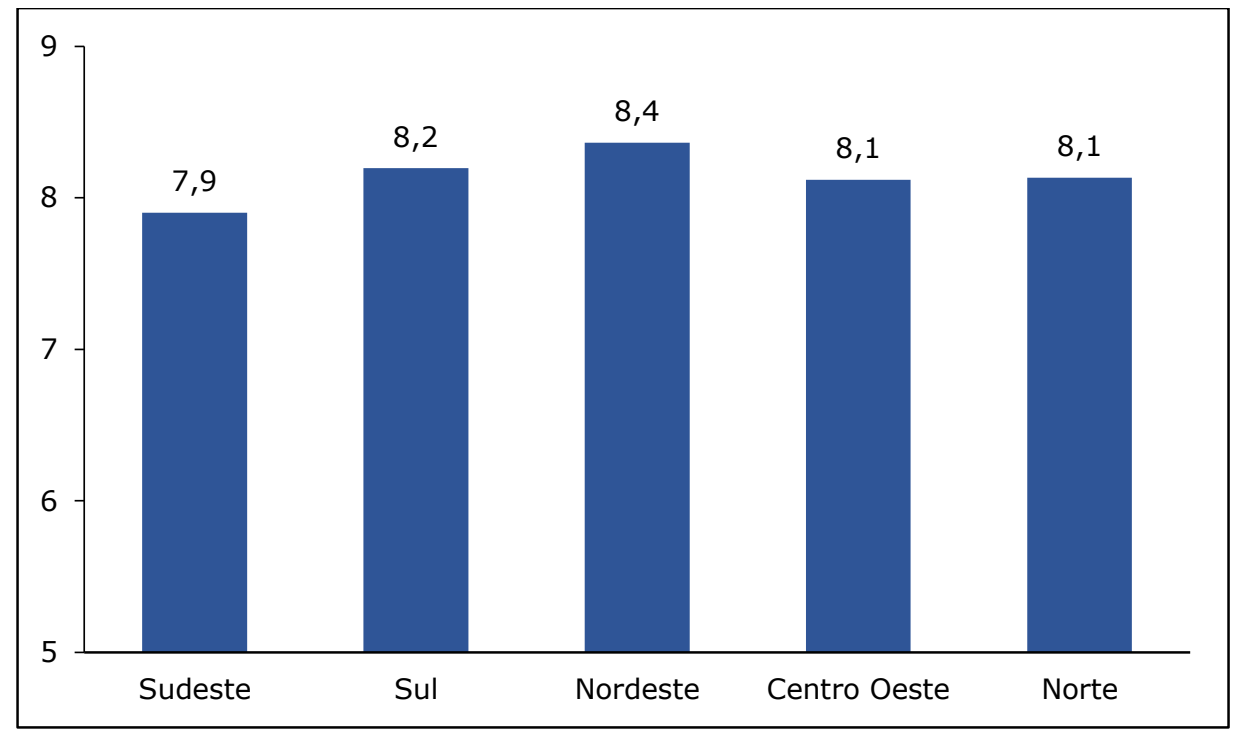

Fonte: Elaborado pelos autores com base em dados do Datafolha/Fórum Brasileiro de Segurança Pública (2017).

Ainda em reforço às hipóteses até aqui levantadas, a distribuição da amostra por porte dos municípios em que residiam os entrevistados mostra que há diferenças significativas de médias entre eles $(F=51,525, p<0,001)$. Observa-se uma maior tendência de adesão a posturas autoritárias em municípios de menor porte populacional, com até 50 mil habitantes (Gráfico 5). Nessas localidades, a média do escore observado é um ponto acima daquela medida para os grandes municípios ( 8,6 contra 7,7 , respectivamente), numa evidência de que, em paralelo com as demais variáveis, a dinâmica urbana e espacial das cidades influencia na configuração da propensão e/ou da disposição para aceitar saídas autoritárias. No entanto, também há diferenças significativas entre as médias dos municípios de médio $(M=8,07, D P=1,50)$ porte, pequeno porte ( $M$ $=8,57, \mathrm{DP}=1,36, \mathrm{p}<0,001)$ e grande porte $(\mathrm{M}=7,66, \mathrm{DP}=1,88, \mathrm{p}<0,001)$. $\mathrm{E}$, em um cenário de interiorização da violência criminal, as novas incertezas sociais e econômicas somam-se às tradicionais e, por vezes, violentas e cruéis formas de resolução de conflitos sociais e à insuficiente/seletiva presença do Estado. Há referências morais, políticas e 
institucionais autoritárias sobre como lidar com a nova realidade urbana e rural posta. Isso surge com destaque em municípios menores, mas tende a ser um fenômeno mais amplo.

Gráfico 5

Índice de propensão a posições autoritárias por porte do município

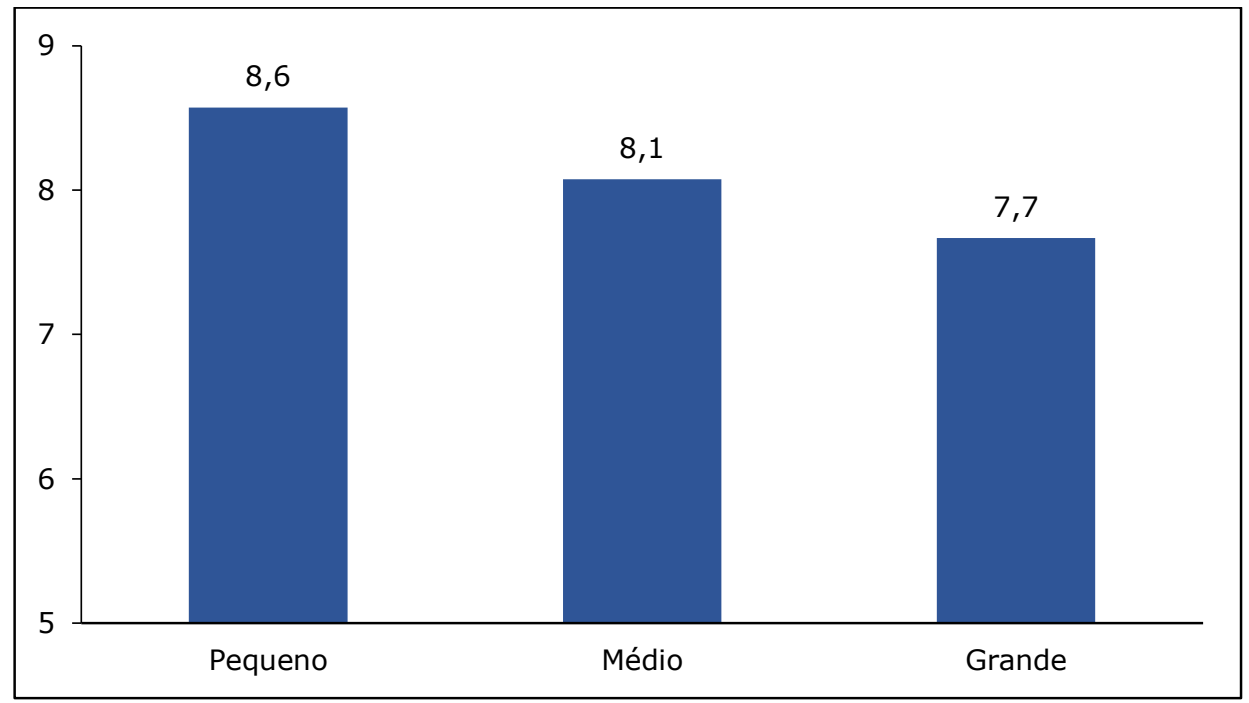

Fonte: Elaborado pelos autores com base em dados do Datafolha/Fórum Brasileiro de Segurança Pública (2017).

Outro importante resultado da pesquisa foi a diferença significativa nas pontuações conforme diferentes níveis de escolaridade $(F=23,492, p<0,001)$. No geral, quanto menor a escolaridade, maior a propensão a posições autoritárias; e, em sentido inverso, à medida que cresce a escolaridade, diminui a propensão a apoiar essas posições (Gráfico 6). Se entre analfabetos o índice atinge 8,4, entre aqueles com ensino superior completo cai para 7,4, patamar ainda alto de adesão ao autoritarismo de todo modo. O resultado mais baixo do escore ocorre apenas na parcela bastante minoritária de pós-graduados ( $M$ $=6,50, \mathrm{DP}=2,13)$. Ainda assim, esse resultado dá certo alento pois permite pensar a educação como fator de contenção de posições autoritárias. 


\section{Gráfico 6}

Índice de propensão ao apoio a posições autoritárias por escolaridade

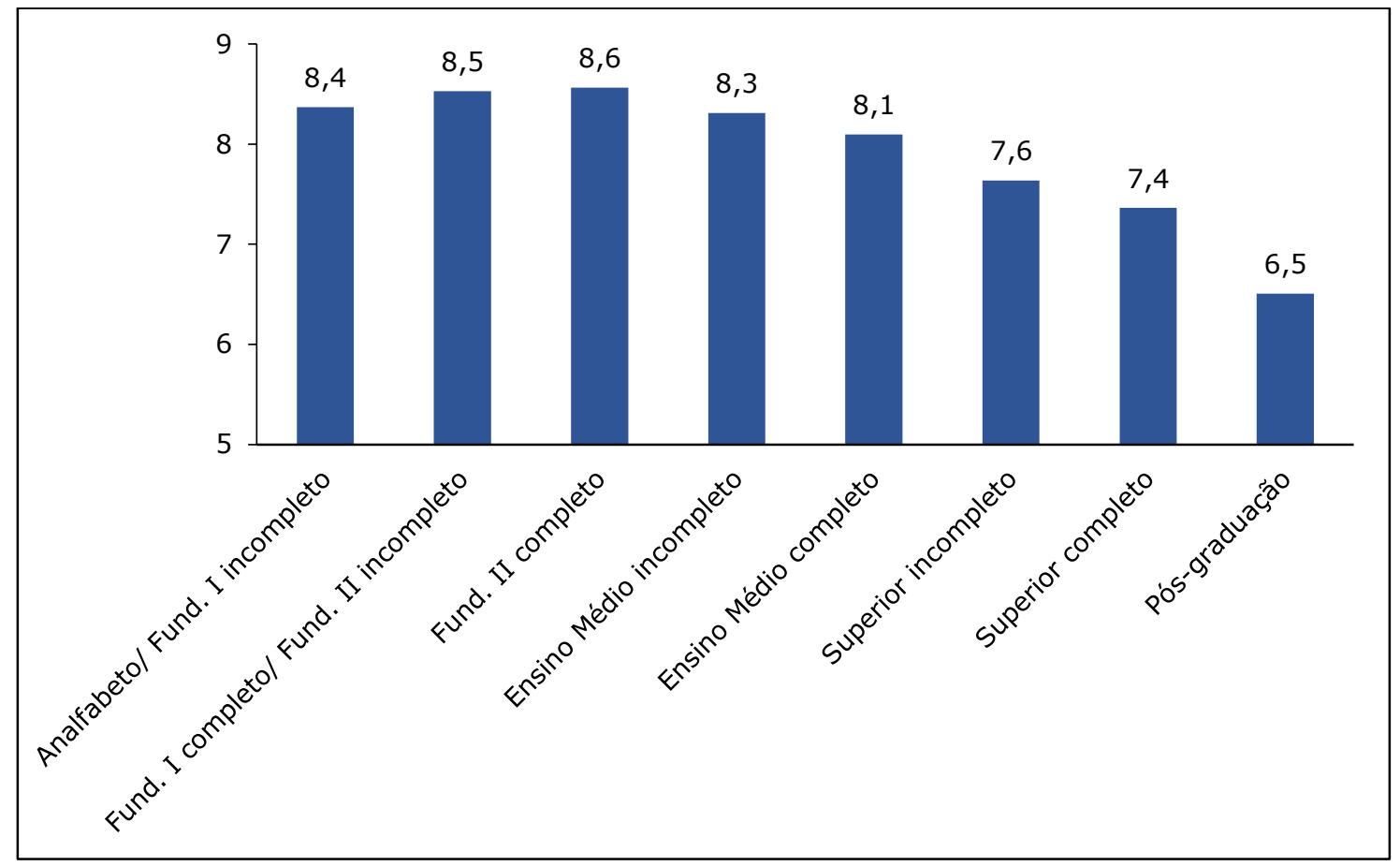

Fonte: Elaborado pelos autores com base em dados do Datafolha/Fórum Brasileiro de Segurança Pública (2017).

Para finalizar, foi comparado o índice de apoio a posições autoritárias nos grupos com maior e menor medo da violência. Identificou-se que há diferenças significativas entre as médias do autoritarismo, sendo que o grupo com maior medo $(M=8,24$, DP $=1,66)$ apresentou um maior índice de apoio a posições autoritárias em relação ao grupo com menor medo $(M=7,88, D P=1,74, p<0,001)$.

\section{À guisa de conclusão: o que pode ser feito para sair dessa situação?}

Como chegamos até aqui, nesse patamar de adesão a posições autoritárias, dimensionado em um nível de 8,1 em uma escala com máximo de 10 ? Se isso já é uma péssima notícia em si, como entender que essa adesão é elevada em qualquer segmento populacional analisado, entre jovens e pessoas mais velhas, entre mais ricos e mais pobres, entre homens e mulheres, entre brancos e negros, residentes no Nordeste ou Sudeste? Os resultados da pesquisa mostram que, felizmente, a adesão ao autoritarismo parece ceder parcialmente à escolarização. Parcialmente, pois a adesão é significativamente mais baixa só entre aqueles com pós-graduação. 
Na realidade, não parece que as escolas estejam contribuindo de forma importante para mitigar ou reverter esse quadro. A natureza marcadamente "desempenhista" da avaliação educacional, como apontado por Horta Neto, Junqueira e Oliveira (2016), não parece colaborar nesse sentido. A preocupação com o desempenho cognitivo dos estudantes - em matemática e português - ou a preparação instrumental para o mundo do trabalho parecem estar muito à frente da preocupação com o desenvolvimento de sociabilidades e valores de cidadania, outro objetivo da política educacional $^{9}$. O "desempenhismo cognitivo" como objetivo final do processo educacional pode estar contribuindo, inclusive, para acirrar posições mais individualistas, discriminatórias e intolerantes dos estudantes - e seus professores - a julgar pelo que se passou recentemente nos EUA ${ }^{10}$. Como bem descreve Bastos (2018), concepções instrumentalistas da educação, levadas a cabo na Lei de Responsabilidade Educacional pelo governo Bush em 2002, vêm sendo acusadas de empobrecimento curricular, desmotivação de professores, desvirtuamento ético na realização dos exames nacionais de aprendizagem e ampliação da segregação socioeducacional naquele país. Tal concepção de qualidade educacional, além de garantir o desempenho cognitivo esperado em matemática e língua inglesa, parece ter comprometido o desenvolvimento no campo dos valores sociomorais e capacidades socioemocionais.

O quadro não parece ser diferente no Brasil. É o que apontam os resultados de estudo piloto de avaliação de sociabilidades em termos de respeito, solidariedade, justiça e convivência democrática em amostra de escolas - públicas e particulares - na Grande São Paulo (Tavares et al., 2016). Crianças e adolescentes não estão com proficiência baixa só em matemática e português, mas também nessas dimensões sociomorais. Com respeito à solidariedade, por exemplo, parcelas ínfimas de estudantes do segundo ciclo do ensino fundamental e do ensino médio atingiram proficiência propriamente desenvolvida nessa dimensão. Muito poucos deles se moveriam, pela aplicação dos instrumentos da pesquisa, "por buscar a igualdade, ou o bem comum, por sensibilizar-se pela necessidade do outro, ou, ainda, por compartilhar sentimentos e perspectivas" (p. 200). Entre os professores, o quadro é, felizmente, melhor, mas cerca de $29 \%$ da amostra pesquisada demonstraria uma atitude de solidariedade "na maioria das vezes movida por atender às convenções sociais e por obediência ou manutenção das regras" (p. 200) ${ }^{11}$.

Como mostram os autores, a importância de cuidar do desenvolvimento desses valores entre estudantes estaria respaldada não só por extensa relação de pesquisas e

\footnotetext{
9 Como preconiza o artigo 205 da Constituição Federal de 1988 "A educação, direito de todos e dever do Estado e da família, será promovida e incentivada com a colaboração da sociedade, visando ao pleno desenvolvimento da pessoa, seu preparo para o exercício da cidadania e sua qualificação para o trabalho". 10 Um estudante de 19 anos, expulso da escola por questões disciplinares, cometeu um atentado com 17 mortes em uma escola na cidade de Parkland (Flórida) em fevereiro de 2018. Disponível em: (<https://www1.folha.uol.com.br/mundo/2018/02/atirador-deixa-feridos-em-escola-na-florida.shtml>). Acesso em: 2 abr. 2020.

11 Em termos de uma escala linear, entre o intervalo de 18 a 177 pontos, tomando a proficiência de solidariedade de crianças com nível 100, a dos adolescentes seria de 111, e dos professores, 167.
} 
experiências na área como, inclusive, em diversas normas brasileiras, da Constituição aos Parâmetros Curriculares Nacionais. Não há como negar o papel fundamental da escola nessa questão.

A construção de relações mais justas e respeitosas e dos valores sociomorais nelas inseridos são (sic), sem dúvida, metas importantes para a educação, e a escola, dependendo da qualidade das interações estabelecidas em seu interior, constitui-se num local propício para que esse desenvolvimento ocorra (...).

Constatamos que valores como solidariedade, justiça, respeito e convivência democrática estão sempre presentes nos objetivos dos projetos políticopedagógicos e nas falas dos professores. Contudo, não basta um projeto para autonomia, é preciso oferecer um ambiente escolar que seja, efetivamente, propício para tal conquista (Tavares et al., 2016, p. 206).

Se um instrumento semelhante fosse desenvolvido e aplicado para dimensionar a adesão a valores sociomorais em estudantes e professores universitários, seriam os resultados muito melhores? Talvez não, pois a vida universitária já começa bastante competitiva no vestibular, e a competição persiste por alguns anos nas disputas por bolsas de estudo, estágios profissionais, vagas para auxiliares de pesquisa, submissão de artigos para congressos e revistas científicas. As pressões competitivas não arrefecem na saída da universidade, nos processos seletivos de contratação profissional, nas exigências de credenciais de formação e experiência, no esforço requerido em concursos públicos ou exames profissionais (para advogados, por exemplo).

Enquanto não se desenvolve tal instrumento, talvez se possa replicar a metodologia de análise de conteúdo dos projetos políticos pedagógicos dos cursos, usada por Dias et al. (2018) na avaliação dos "resultados de aprendizagem" almejados nos cursos de engenharia em Portugal. A frequência com que termos como "competências", "capacidades" e "conhecimentos" aparecem nos documentos aponta a prevalência do desenvolvimento cognitivo na formação dos engenheiros. A análise dos autores revelou também que o desenvolvimento de competências transversais, referidas às atitudes, valores e formas de pensar e de agir em contextos de mudança tecnológica e social, é menos presente.

Adesão a valores do autoritarismo diz muito sobre as manifestações de preconceito, discriminação e intolerância nas mídias sociais, nas ruas, nas reuniões de amigos e familiares no país. Buscar saídas para esse quadro disruptivo em que o Brasil se encontra requer, certamente, o conhecimento de como a agenda de cidadania, solidariedade, respeito e outros valores sociomorais está sendo trabalhada em processos formativos, da escola à universidade. 
Mas, ao buscarmos essas frentes todas, os dados contidos no estudo "Medo da violência e autoritarismo no Brasil" (FBSP - Fórum Brasileiro de Segurança Pública, 2017), que, além do estudo aqui detalhado, inclui uma hipótese contrafactual de acesso a direitos (que não se confirmou), sugerem uma combinação de elementos simbólicos. Por um lado, esses elementos reforçam a desigualdade estrutural da sociedade brasileira ao demonstrar que, entre os mais ricos, a ampliação de direitos parece ser compreendida como ameaça a privilégios de classe vistos como conquistados por "meritocracia" - como é o caso de $51 \%$ dos entrevistados pelo estudo, que declararam que a Lei das Domésticas interfere indevidamente nas relações entre patrões e empregados. Por outro lado, a maior adesão dos mais pobres e menos escolarizados às tendências autoritárias parece sugerir uma forte fadiga com a ineficiência das políticas públicas, abrindo espaço para o reforço de posições salvacionistas e autoritárias.

Em conclusão, a forte adesão às posições autoritárias medidas pela escala $F$ adaptada à realidade brasileira está fortemente correlacionada com um fator que devemos considerar chave na determinação dos movimentos das representações sociais sobre democracia e autoritarismo no Brasil: o medo da violência, que tem sido eficazmente explorado pelos porta-vozes da extrema direita política para o reforço do pânico moral que tem tomado conta do Ocidente nos últimos anos e que, no país, é traduzido como fruto da "frouxidão" das leis penais e da "imposição" de uma agenda "globalista" e "esquerdista" de direitos humanos e sociais. Como coloca Lima (2018, p. 170):

A violência continua sendo vista como legítima resposta ao crime, em um movimento que reforça a manutenção de ordem como a imposição de um único e hegemônico modelo de comportamento e projeto nacional, engendrado antes do ciclo de transição para a democracia. Nesse movimento, parece que a cidadania continuará a ser garantida apenas por uma parcela da população, ou seja, aqueles que merecem o rótulo de "cidadão de bem", já que, em relação aos "bandidos", a percepção é de que eles possam ser eliminados. O drama contemporâneo é que as declarações universais de direitos, entre outras normas nacionais e internacionais, tinham sido capazes de ao menos mudarem tais discursos. No entanto, vivemos uma nova onda impulsionada pelo tempo social da direita que bloqueia o debate político e coloca em risco os avanços na agenda de direitos feitos em 1988 com a promulgação da Constituição Federal (Lima, 2018, p. 170).

Para a ultradireita brasileira, a agenda de direitos civis, políticos e sociais da Constituição brasileira é a responsável pela decadência "moral" e "cívica" da nação e apenas com a retomada da "autoridade" e de políticas criminais baseadas no enfrentamento do inimigo é que o país poderá voltar a ter tranquilidade e paz. Por trás desse engenhoso processo comunicacional, em muito reposto pelas novas linguagens das redes sociais, o autoritarismo é retroalimentado como referência para o sentido das 
relações sociais da nossa sociedade. Porém, todo esse processo deriva do medo da violência, que, por sua vez, nunca foi moral ou politicamente interditada pelas políticas públicas brasileiras e é a principal chave explicativa para o novo ciclo de (retro)adesão a valores autoritários.

Enfim, se queremos avançar na contenção do autoritarismo em suas diferentes formas e contextos ou na redução da pobreza e da desigualdade, na melhoria da educação e na garantia da cidadania ou, teremos que oferecer saídas para o drama do medo da violência.

\section{Referências bibliográficas}

Adorno, S.; Dias, C. N. Monopólio estatal da violência. In: Lima, R. S.; RATTON, J. L.; AzeVedo, R. G. (orgs.). Crime, polícia e justiça no Brasil. São Paulo: Contexto, vol. 1, p. 187-197, 2014.

Adorno, T. W., et al. The authoritarian personality. New York: Harper and Row, 1950.

Barros, T. S.; Torres, A. R. R.; Pereira, C. "Autoritarismo e adesão a sistemas de valores psicossociais". Psico-USF, vol. 1, no 14, p. 47-57, jan.-abr. 2009.

BASTOS, R. M. B. "O papel dos testes padronizados na política educacional para ensino básico nos Estados Unidos". Ensaio: Avaliação e Políticas Públicas em Educação, Rio de Janeiro, vol. 26, no 99, p. 418-444, 2018.

Bernal, A. O. "El autoritarismo: enfoque psicológico". El Basilico, no 13, p. 40-44, jun. 1982.

CÁRDENAS, M.; PARRA, L. "Adaptación y validación de la versión abreviada de la escala de autoritarismo de derechas (RWA) en una muestra chilena". Revista de Psicologia, vol. 1, no 19, p. 61-79, 2010.

CRochík, J. L. "Preconceito: relações com a ideologia e com a personalidade". Estudos de Psicologia, Campinas, vol. 22, no 3, p. 307-319, 2005.

. "Personalidade autoritária e pesquisa empírica com a escala $\mathrm{F}$ : alguns estudos brasileiros". Impulso, Piracicaba, vol. 27, no 69, p. 49-64, 2017.

CODO, W. Relações de trabalho e transformação social. In: LANE, S. T. M.; CODO, W. (orgs.). Psicologia social: o homem em movimento. $13^{\circ}$ ed. São Paulo: Brasiliense, 1994.

CosTA, A. B., et al. "Prejudice toward gender and sexual diversity in a Brazilian public university: prevalence, awareness, and the effects of education". Sexuality Research and Social Policy, vol. 12, no 4, p. 261-272, 2015.

DIAS, D., et al. "O que se 'ensina' no ensino superior: avaliando conhecimentos, competências, valores e atitudes". Meta: Avaliação, Rio de Janeiro, vol. 10, no 29, p. 318-337, maio-ago. 2018.

ETCHeZAHAR, E. "Las dimensiones del autoritarismo: análisis de la escala de autoritarismo del ala de derechas (RWA) en una muestra de estudiantes universitarios de la ciudad de Buenos Aires". Psicologia Política, vol. 12, no 25, p. 591-603, set.-dez. 2012.

FOA, R. S.; Mounk, Y. "The democratic disconnect". Journal of Democracy, vol. 27, no 3, jul. 2016. 
FBSP - Fórum Brasileiro de Segurança Pública. "Medo da violência e apoio ao autoritarismo no Brasil", Texto para discussão, no 1, São Paulo, 2017.

FRENKEL-BRUNSWIK, E.; SANFORD, R. N. "Some personality factors in anti-semitism". The Journal of Psychology, vol. 20, no 2, p. 271-291, 1945.

Fromm, E. O medo à liberdade. 14a ed. Rio de Janeiro: Guanabara Koogan, 1983.

GRosfogueL, R. "A estrutura do conhecimento nas universidades ocidentalizadas: racismo/sexismo epistêmico e os quatro genocídios/epistemicídios do longo século XVI". Sociedade e Estado, vol. 31, no 1, p. 25-49, 2016.

Horta Neto, J. L.; Junqueira, R. D.; Oliveira, A. S. "Do Saeb ao Sinaeb: prolongamentos críticos da avaliação da educação básica". Em Aberto, vol. 29, no 96, p. 21-37, 2016.

JANNUZzi, P. M. "Eficiência econômica, eficácia procedural ou efetividade social: três valores em disputa na avaliação de políticas e programas sociais". Desenvolvimento em Debate, vol. 4, no 1, p. 117-142, 2016.

LIMA, R. S. "Violence and public safety as a democratic simulacrum in Brazil". International Journal of Criminology and Sociology, vol. 7, p. 159-172, 2018.

Mbembe, A. Políticas da inimizade. Lisboa: Antígona Editores Refractários, 2017.

Moura JR., J. F.; Ximenes, V. M.; SARriera, J. C. "A construção opressora da pobreza no Brasil e suas consequências no psiquismo". Quaderns de Psicologia, vol. 16, n 2, p. 85-93, 2014.

NARAYAN, D. Voices of the poor: can anyone hear us? World Bank Publication, 2000.

NogueIRA, O. "Preconceito racial de marca e preconceito racial de origem: sugestão de um quadro de referência para a interpretação do material sobre relações raciais no Brasil". Tempo Social, vol. 19, no 1 , p. 287-308, 2007.

PALUCK, E. L.; GREen, D. P. "Prejudice reduction: what works? A review and assessment of research and practice". Annual Review of Psychology, vol. 60, p. 339-367, 2009.

Pinheiro, P. S. "Autoritarismo e transição". Revista USP, no 45, 1991.

SALLES, M. M.; BARRos, S. "Inclusão social de pessoas com transtornos mentais: a construção de redes sociais na vida cotidiana". Ciência \& Saúde Coletiva, vol. 18, no 7, p. 2.129-2.138, 2013.

Schwartzman, S. Bases do autoritarismo brasileiro. Rio de Janeiro: Publit Soluções Editoriais, 2007.

SPRANDEL, M. A. A pobreza no paraíso tropical: interpretações e discursos sobre o Brasil. Rio de Janeiro: Relume Dumará, 2004.

TAVARES, M. R., et al. "Construção e validação de uma escala de valores sociomorais". Cadernos de Pesquisa, vol. 46, no 59, p. 186-210, jan.-mar. 2016.

TeixeirA, J. B.; Polo, A. "A personalidade autoritária: componentes e gênese psicológica". Arquivo Brasileiro de Psicologia Aplicada. Rio de Janeiro, vol. 27, no 4, out.-dez. 1975. 
Anexo

Questionário Geral

Fórum Brasileiro de Segurança Pública/Datafolha

1. UF:

2. Idade:

3. Sexo: (1) Masculino ( 2 ) Feminino

Você diria que tem medo de... (LEIA CADA ITEM ) [ESTIMULADA E ÚNICA POR LINHA]

P.1b (P.1a = 1) Se sim, muito medo ou pouco medo?

APLIQUE RODÍZIO

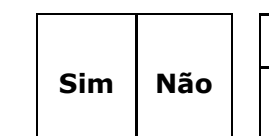

\begin{tabular}{|c|c|c|}
\hline 4. Ter sua residência invadida ou arrombada? & 1 & 2 \\
\hline $\begin{array}{l}\text { 5. Ter objetos pessoais de valor tomados à força } \\
\text { por outras pessoas em um roubo }\end{array}$ & 1 & 2 \\
\hline $\begin{array}{l}\text { 6. Ter seu carro ou moto tomado de assalto ou } \\
\text { furtados }\end{array}$ & 1 & 2 \\
\hline $\begin{array}{l}\text { 7. Se envolver em brigas ou agressões físicas com } \\
\text { outras pessoas }\end{array}$ & 1 & 2 \\
\hline 8. Morrer assassinado? & 1 & 2 \\
\hline 9. Ser sequestrado & 1 & 2 \\
\hline 10. Sofrer sequestro relâmpago & 1 & 2 \\
\hline 11. Ser vítima de agressão sexual & 1 & 2 \\
\hline $\begin{array}{l}\text { 12. Ser vítima de uma fraude e perder quantia } \\
\text { significativa de dinheiro }\end{array}$ & 1 & 2 \\
\hline $\begin{array}{l}\text { 13. Receber uma ligação de bandidos exigindo } \\
\text { dinheiro }\end{array}$ & 1 & 2 \\
\hline $\begin{array}{l}\text { 14. Ser vítima de violência por parte da Polícia } \\
\text { Militar, aquela que executa o policiamento } \\
\text { fardado e ostensivo nas ruas }\end{array}$ & 1 & 2 \\
\hline $\begin{array}{l}\text { 15. Ser vítima de violência por parte da Polícia Civil, } \\
\text { aquela que atua investigando crimes e registra } \\
\text { ocorrência nas delegacias }\end{array}$ & 1 & 2 \\
\hline 16. Ter o celular furtado ou roubado & 1 & 2 \\
\hline $\begin{array}{l}\text { 17. Ter os seus conteúdos pessoais divulgados na } \\
\text { internet }\end{array}$ & 1 & 2 \\
\hline 18. Ter parentes envolvidos com drogas & 1 & 2 \\
\hline 19. Andar na vizinhança depois de anoitecer & 1 & 2 \\
\hline
\end{tabular}

\begin{tabular}{|c|c|c|}
\hline & \multirow{2}{*}{$\begin{array}{l}\text { Não } \\
\text { sabe }\end{array}$} \\
\hline $\begin{array}{l}\text { Muito } \\
\text { Medo }\end{array}$ & $\begin{array}{c}\text { Pouco } \\
\text { Medo }\end{array}$ & \\
\hline 3 & 4 & 99 \\
\hline 3 & 4 & 99 \\
\hline 3 & 4 & 99 \\
\hline 3 & 4 & 99 \\
\hline 3 & 4 & 99 \\
\hline 3 & 4 & 99 \\
\hline 3 & 4 & 99 \\
\hline 3 & 4 & 99 \\
\hline 3 & 4 & 99 \\
\hline 3 & 4 & 99 \\
\hline 3 & 4 & 99 \\
\hline 3 & 4 & 99 \\
\hline 3 & 4 & 99 \\
\hline 3 & 4 & 99 \\
\hline 3 & 4 & 99 \\
\hline 3 & 4 & 99 \\
\hline
\end{tabular}


Em uma escala de 0 a 10, onde 0 significa nenhuma chance de acontecer e 10 muita chance de acontecer, qual a chance de (LEIA CADA ITEM ) [ESTIMULADA E ÚNICA POR LINHA]

\section{APLIQUE RODÍZIO}

20. Ter sua residência invadida ou arrombada no próximo mês?

21. Ter objetos pessoais de valor tomados à força por outras pessoas em um roubo no próximo mês

22. Ter seu carro ou moto tomado de assalto ou furtados no próximo mês

23. Se envolver em brigas ou agressões físicas com outras pessoas no próximo mês

24. Morrer assassinado no próximo mês

25. Ser sequestrado no próximo mês

26. Sofrer sequestro relâmpago no próximo mês

27. Ser vítima de agressão sexual no próximo mês

28. Ser vítima de uma fraude e perder quantia significativa de dinheiro no próximo mês

29. Receber uma ligação de bandidos exigindo dinheiro no próximo mês

30. Ser vítima de violência por parte da Polícia Militar, aquela que executa o policiamento fardado e ostensivo nas ruas no próximo mês

31. Ser vítima de violência por parte da Polícia Civil, aquela que atua investigando crimes e registra ocorrência nas delegacias no próximo mês

32. Ter o celular furtado ou roubado no próximo mês

33. Ter os seus conteúdos pessoais divulgados na internet no próximo mês

34. Ter parentes envolvidos com drogas no próximo mês

35. Andar na vizinhança depois de anoitecer no próximo mês

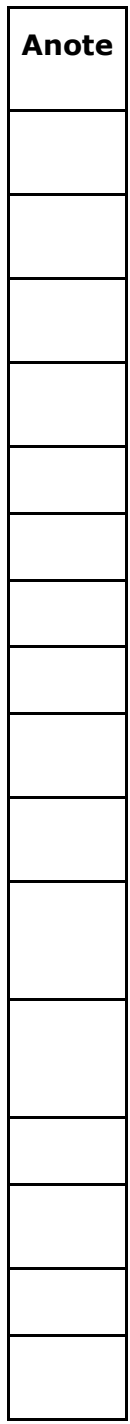


No último mês: (LEIA CADA ITEM ) [ESTIMULADA E ÚNICA POR LINHA]

\section{APLIQUE RODÍzIO}

36. Sua residência foi invadida ou arrombada

37. Ser roubado, assaltado ou furtado em casa, no transporte ou na escola/trabalho?

38. Seu carro ou moto tomado de assalto ou furtados

39. Se envolveu em brigas ou agressões físicas com outras pessoas

40. Foi sequestrado

41. Sofreu sequestro relâmpago

42. Foi vítima de agressão sexual

43. Foi vítima de uma fraude e perdeu quantia significativa de dinheiro

44. Recebeu uma ligação de bandidos exigindo dinheiro

45. Foi vítima de violência por parte da Polícia Militar, aquela que executa o policiamento fardado e ostensivo nas ruas

46. Foi vítima de violência por parte da Polícia Civil, aquela que atua investigando crimes e registra ocorrência nas delegacias

47. Teve o celular furtado ou roubado

48. Teve os seus conteúdos pessoais divulgados na internet

49. Teve parentes envolvidos com drogas

50. Andou na vizinhança depois de anoitecer

\begin{tabular}{|c|c|}
\hline SIM & NAO \\
\hline 1 & 2 \\
\hline 1 & 2 \\
\hline 1 & 2 \\
\hline 1 & 2 \\
\hline 1 & 2 \\
\hline 1 & 2 \\
\hline 1 & 2 \\
\hline 1 & 2 \\
\hline 1 & 2 \\
\hline 1 & 2 \\
\hline 1 & 2 \\
\hline 1 & 2 \\
\hline 1 & 2 \\
\hline 1 & 2 \\
\hline 1 & 2 \\
\hline
\end{tabular}


Vou ler algumas frases e gostaria que você me dissesse se concorda ou discorda de cada uma delas (LEIA CADA ITEM). Você concorda ou discorda? (SE CONCORDA OU DISCORDA) Totalmente ou em parte? (ESTIMULADA E ÚNICA)

\begin{tabular}{|c|c|c|c|c|c|c|c|c|}
\hline & Aplique o rodízio & $\begin{array}{l}\text { Concorda } \\
\text { totalmente }\end{array}$ & Concorda & $\begin{array}{l}\text { Concorda } \\
\text { em parte }\end{array}$ & $\begin{array}{l}\text { Discorda } \\
\text { em parte }\end{array}$ & Discorda & $\begin{array}{l}\text { Discorda } \\
\text { totalmente }\end{array}$ & Não sabe \\
\hline 51 & $\begin{array}{l}\text { O que este país necessita, } \\
\text { principalmente, antes de leis ou } \\
\text { planos políticos, é de alguns } \\
\text { líderes valentes, incansáveis e } \\
\text { dedicados em quem o povo } \\
\text { possa depositar a sua fé. }\end{array}$ & 1 & 2 & 3 & 4 & 5 & 6 & 99 \\
\hline 52 & $\begin{array}{l}\text { A maioria de nossos problemas } \\
\text { sociais estaria resolvida se } \\
\text { pudéssemos nos livrar das } \\
\text { pessoas imorais, dos marginais e } \\
\text { dos pervertidos. }\end{array}$ & 1 & 2 & 3 & 4 & 5 & 6 & 99 \\
\hline 53 & $\begin{array}{l}\text { A obediência e o respeito à } \\
\text { autoridade são as principais } \\
\text { virtudes que devemos ensinar às } \\
\text { nossas crianças. }\end{array}$ & 1 & 2 & 3 & 4 & 5 & 6 & 99 \\
\hline 54 & $\begin{array}{l}\text { Os homens podem ser divididos } \\
\text { em duas classes definidas: os } \\
\text { fracos e os fortes. }\end{array}$ & 1 & 2 & 3 & 4 & 5 & 6 & 99 \\
\hline 55 & $\begin{array}{l}\text { Deve-se castigar sempre todo } \\
\text { insulto à nossa honra. }\end{array}$ & 1 & 2 & 3 & 4 & 5 & 6 & 99 \\
\hline 56 & $\begin{array}{l}\text { A ciência tem o seu lugar, mas } \\
\text { há muitas coisas importantes } \\
\text { que a mente humana jamais } \\
\text { poderá compreender. }\end{array}$ & 1 & 2 & 3 & 4 & 5 & 6 & 99 \\
\hline 57 & $\begin{array}{l}\text { Os crimes sexuais tais como o } \\
\text { estupro ou ataques a crianças } \\
\text { merecem mais que prisão; quem } \\
\text { comete esses crimes deveria } \\
\text { receber punição física } \\
\text { publicamente ou receber um } \\
\text { castigo pior. }\end{array}$ & 1 & 2 & 3 & 4 & 5 & 6 & 99 \\
\hline 58 & $\begin{array}{l}\text { Hoje em dia, as pessoas se } \\
\text { intrometem cada vez mais em } \\
\text { assuntos que deveriam ser } \\
\text { somente pessoais e privados. }\end{array}$ & 1 & 2 & 3 & 4 & 5 & 6 & 99 \\
\hline
\end{tabular}




\begin{tabular}{|c|c|c|c|c|c|c|c|c|}
\hline 59 & $\begin{array}{l}\text { Um indivíduo de más maneiras, } \\
\text { maus costumes e má educação } \\
\text { dificilmente pode fazer amizade } \\
\text { com pessoas decentes. }\end{array}$ & 1 & 2 & 3 & 4 & 5 & 6 & 99 \\
\hline 60 & $\begin{array}{l}\text { Se falássemos menos e } \\
\text { trabalhássemos mais, todos } \\
\text { estaríamos melhor. }\end{array}$ & 1 & 2 & 3 & 4 & 5 & 6 & 99 \\
\hline 61 & $\begin{array}{l}\text { Todos devemos ter fé absoluta } \\
\text { em um poder sobrenatural, cujas } \\
\text { decisões devemos acatar. }\end{array}$ & 1 & 2 & 3 & 4 & 5 & 6 & 99 \\
\hline 62 & $\begin{array}{l}\text { Não há nada pior do que uma } \\
\text { pessoa que não sente profundo } \\
\text { amor, gratidão e respeito por } \\
\text { seus pais }\end{array}$ & 1 & 2 & 3 & 4 & 5 & 6 & 99 \\
\hline 63 & $\begin{array}{l}\text { Os homossexuais são quase } \\
\text { criminosos e deveriam receber } \\
\text { um castigo severo }\end{array}$ & 1 & 2 & 3 & 4 & 5 & 6 & 99 \\
\hline 64 & $\begin{array}{l}\text { Nenhuma pessoa decente, } \\
\text { normal e em seu são juízo } \\
\text { pensaria em ofender um amigo } \\
\text { ou parente próximo }\end{array}$ & 1 & 2 & 3 & 4 & 5 & 6 & 99 \\
\hline 65 & $\begin{array}{l}\text { O policial é um guerreiro de } \\
\text { Deus para impor a ordem e } \\
\text { proteger as pessoas de bem. }\end{array}$ & 1 & 2 & 3 & 4 & 5 & 6 & 99 \\
\hline 66 & $\begin{array}{l}\text { Às vezes, os jovens têm ideias } \\
\text { rebeldes que, com os anos, } \\
\text { deverão superar para acalmar os } \\
\text { seus pensamentos }\end{array}$ & 1 & 2 & 3 & 4 & 5 & 6 & 99 \\
\hline 67 & $\begin{array}{l}\text { Pobreza é consequência da falta } \\
\text { de vontade de querer trabalhar }\end{array}$ & 1 & 2 & 3 & 4 & 5 & 6 & 99 \\
\hline
\end{tabular}

68. Qual sua cor?

(1) Branca

( 2) Preta

(3) Parda

(4) Amarela

( 5) Indígena 
Agora, vou mencionar alguns bens de consumo e você me diz quantos possui:

69. Automóveis de passeio exclusivamente de uso particular? Quantos?

70. Empregados mensalistas, considerando apenas os que trabalham pelo menos 5 dias na semana? Quantos?

71. Máquinas de lavar roupas, excluindo tanquinho? Quantas?

72. Aparelho de DVD, incluindo qualquer outro dispositivo que leia DVD? Quantos?

73. Banheiros? Quantos?

74. Geladeira? Quantas?

75. Freezer independente ou aquele que faz parte da geladeira "duplex"? Quantos?

76. Microcomputador, considerando computadores de mesa, lap tops, notebooks e netbooks e excluindo tablets, palms ou smartphones? Quantos?

77. Máquina de lavar louças? Quantas?

78. Fornos de micro-ondas? Quantos?

79. Motocicletas, desconsiderando as que são utilizadas exclusivamente para fins profissionais? Quantas?

80. Máquina secadora de roupas? Quantas?

81. Até que ano da escola o chefe da família estudou?

( 1 ) Analfabeto

( 2 ) Primário ou Fundamental I Completo

( 3 ) Ginasial ou Fundamental II Completo

( 4 ) Colegial ou Ensino Médio Incompleto

( 5 ) Colegial ou Ensino Médio Completo

( 6 ) Superior Incompleto

( 7 ) Superior Completo

( 8 ) Pós-graduação

( 9 ) Recuso 
82. Renda Individual Mensal

(1) "Até 2 S.M."

( 2) "Mais de 2 a 3 S.M."

( 3 ) "Mais de 3 a 5 S.M."

( 4 ) "Mais de 5 a 10 S.M."

( 5 ) "Mais de 10 a 20 S.M."

( 6 ) "Mais de 20 a 50 S.M."

( 7 ) "Mais de 50 S.M."

( 97 ) "Recusa"

(99 ) "Não sabe"

82. Voce mora em qual cidade?

\begin{abstract}
Fear of violence and adherence to authoritarianism in Brazil: methodological proposal and results in 2017

This article examines support to authoritarian positions from Brazilian population and dialogues with concerns about recent democratic disruptions and strengthening of antidemocratic positions post-30 years of the Federal Constitution. For this purpose, a survey was conducted with a representative sample of the adult population from the age of 16 years. 2,087 people interviewees answered a version of 17 items of the Adorno's authoritarianism scale (F Scale). The results indicate a strong adherence to authoritarian positions in all layers of society but even more intense for historically marginalized social segments. The fear of violence, which has been effectively exploited by the spokesmen of the extreme right-wing politician's to reinforce moral panic, may have been the propeller of authoritarian tendencies.
\end{abstract}

Keywords: authoritarianism; Brazil; fear; democracy

\title{
Resumen
}

Miedo a la violencia y adherencia al autoritarismo en el Brasil: propuesta metodológica y resultados en 2017

El presente artículo examina el apoyo a posiciones autoritarias de la población brasileña y, de forma amplia, dialoga con las preocupaciones con los recientes rompimientos democráticos y fortalecimientos de posiciones antidemocráticas post-30 años de la Constitución Federal. Para ello, se realizó un levantamiento con una muestra representativa de la población adulta a partir de los 16 años. Se entrevistaron a 2.087 personas que respondieron a una versión de 17 ítems de la escala de autoritarismo de Adorno (Escala F). Los resultados indican una fuerte adhesión a las posiciones 
autoritarias en todos los estratos sociales, pero aún más intensas para segmentos sociales históricamente marginados. El miedo de la violencia, que ha sido eficazmente explotado por los portavoces de la extrema derecha política para el refuerzo del pánico moral, puede haber sido el propulsor de las tendencias autoritarias.

Palabras clave: autoritarismo; Brasil; miedo; democracia

\section{Résumé}

Peur de la violence et adhésion à l'autoritarisme dans le Brésil proposition méthodologique et résultats en 2017

Cet article examine le soutien aux positions autoritaires de la population brésilienne et, de manière générale, dialogue avec les préoccupations suscitées par les récentes ruptures démocratiques et le renforcement des positions antidémocratiques après 30 ans de la Constitution Fédérale. Pour cela, une enquête a été réalisée avec un échantillon représentatif de la population adulte à partir de 16 ans. Nous avons interrogé 2087 personnes qui ont répondu à une version de 17 éléments de l'échelle d'autoritarisme d'Adorno (échelle F). Les résultats indiquent une forte adhésion aux positions autoritaires dans toutes les couches sociales, mais encore plus intense pour les segments sociaux historiquement marginalisés. La peur de la violence, qui a été efficacement exploitée par les porteparole de l'extrême droite politique pour renforcer la panique morale, a peut-être été le moteur des tendances autoritaires.

Mots-clés: autoritarisme; Brésil; peur; démocratie

Artigo submetido à publicação em 20 de outubro de 2018 . Versão final aprovada em 3 de dezembro de 2019.

Opinião Pública adota a licença Creative Commons CC-BY. 